\title{
Food availability, accessibilty and nutritional status of low income households of selected Federal tertiary institutions in Kaduna state, Nigeria
}

\author{
Odunze, I.I. ${ }^{1}$, E. Ike; ${ }^{2}$ E. E. Adamu, ${ }^{2}$ and A. Z. Mohammed $^{2}$ \\ ${ }^{1}$ Home and Rural Economics Samaru College of Agriculture, Division of Agricultural Colleges \\ Ahmadu Bello University, Zaria. \\ ${ }^{2}$ Department of Vocational and Technical Education, Faculty of Education \\ Ahmadu Bello University, Zaria.
}

Corresponding Author's Email: finefaceivy@gmail.com

\begin{abstract}
The study determined food availability, accessibility and consumption pattern and nutritional status of low-income households of selected Federal tertiary institutions in Kaduna state, Nigeria. The population comprised of low-income households of Federal tertiary institutions in Kaduna state. A sample of 232 households was drawn purposively from the population. Data were analyzed using descriptive statistics (frequency percentage and mean). Statistical Package for the Social Sciences (SPSS) $17^{\text {th }}$ version was used to test null hypotheses at $\mathrm{P}<0.005$ level of significance. The findings indicate that food accessibility and consumption pattern of households had significant relationship with low-income households nutritional status. Recommendations were made based on the findings.
\end{abstract}

Key Words: Food Availability, Food Accessibility, Consumption Pattern, Nutritional Status, Low-Income Households

\section{INTRODUCTION}

Human beings need food to grow and carry out their daily activities. Therefore, they need these foods in quantity and quality for healthy and productive life. World Food Security (1996) defined food security as a situation in which people at all time have physical and economic access to sufficient, safe and nutritious food to meet their dietary need and food preferences for active healthy life. This implies that people at all levels must have enough food to eat at all times; these foods must be safe from all contaminations, must be adequate and have varieties for a healthy life. Food security is people oriented. It accounts for a substantial part of household budget (Ohwovoriole and Ochonogor, 2009); implying that households must have access to adequate foods and should not be at risk of not insufficient food to meet their dietary needs. The concept of food security has three key elements; namely, food availability, food accessibility and food utilization. Food availability connotes physical presence of food in sufficient quantity. Accessibility suggests sufficient purchasing power or ability to acquire sufficient quality food at all times, while utilization suggests sufficient quantity and quality of food intake (Omonona and Adetokumbo, 2007).

Food availability means having food. This entails production and storage for off seasons. It means availability of food when there are adequate quantities of good foodstuffs so as to provide the nourishing elements and calories necessary. It implies also the availability of foods by households and supply of foods in a nation, region or locality. The sources of supply may include home production, food stocks, imports, food aids and domestic food (Omonona et al., 2007). Production is a means to achieving adequate food availability. However production strategies; such as a nation relying on 
importation of food, may not be the best way or means for ensuring food availability as this may be a costly way of procuring domestic food needs.

Food availability is a function of a combination of domestic food stocks and domestic food production among others. Total availability combines both foods available from production and from imports. Domestic production is food produced and acquired through the physical efforts by household members. This can be from crop production, animal production, fishing, or hunting and others that are then consumed by household members. Some food items acquired by household members when in surplus are traded for other ones that are in shortage or not available at all for exchange for cash. With the farm household, food availability ensures that sufficient food is available through own production. The Problem families' faces today are lack of adequate food storage facilities and competing household needs. When they are not able to store enough food, they end up selling produce during harvesting period and sometimes purchase from the market during hunger period (Obamiro, Doppler, and Kormawa, 2003).

Food availability viewed by policy maker is a selfsufficiency situation. Studies in Nigeria indicate that adequate availability of food in Nigeria on a per capita basis does not necessarily translate to sufficient and adequate food for every citizen. According to Zoellick, (2008), Nigeria is endowed with vast expanse of arable land for crop production and fresh waters for fish breeding. However she is not able to produce sufficient food crops her population requires. This has made her depend on food importation to meet domestic demands. Strategies to increase national and regional food availability and food production may be linked to improved food access by stimulating broad based growth in rural household incomes in both farm and non-farm, and reducing food prices (for net food buyers). Polices or intervention through dissemination of improved agricultural technologies can improve income or prices for low income households; to help in reducing hunger in Nigerian households

Food accessibility is an important element of food security because, even when food is in sufficient quantity, all individuals and families need to have access to them both physically and economically. All stages of food chain supply have some influence on physical accessibility, particularly transportation, storage, and marketing of these food commodities. Economic accessibility or purchasing power of household income is considered the most important factor affecting people's accessibility to healthy and nourishing foods (Obamiro et al., 2003). Idachaba (2004) explained that access to food by all households imply that at food security status, majority of the populace must meet minimum nutritional standards and have assured access to food at all times (without fluctuation in food availability) in homes.
Similarly, access by all people at all times to enough food for active, healthy life would mean that every individual in any society is entitled to have enough food that would sustain him in order to be useful to himself, his family and society throughout life. It implies still that at a minimum the food available should contain all the essential nutrients and be prepared in a hygienic environment (Anderson, 1990). It is also believed that the ability to acquire food must be through socially acceptable ways not through struggling and stealing. Lack of access to nutritionally adequate diet in a household can occur when there is chronic food insecurity that results to persistent insufficient food supplies to low income families which can lead to inadequate nutrition for all members of the family.

Adequate food utilization is realized when food is properly used, proper food processing and storage techniques are employed, adequate knowledge of nutrition and child care techniques exists and is applied, and adequate health and sanitation services exist (USAID, 2002). Similarly, effective food utilization depends in large measure on knowledge within the household of food storage and processing techniques, basic principles of nutrition and proper childcare, and illness management. Food utilization involves how food is used. This can include how often meals are eaten and of what they consist. It should ensure an adequate, consistent and dependable supply of energy and nutrients through sources that are affordable and socioculturally acceptable to them at all times. To this extent, the nutritional status of low income households in Federal tertiary institutions in Kaduna state will result from balanced food intake and normal utilization of nutrients occasioned by food security. Other combined factors affecting nutritional status include limited access to food, inadequate dietary intake and infectious disease(s).

It is on this premise that this study intends to determine the food availability, accessibility and consumption pattern of low- income households of selected Federal Tertiary Institutions in Kaduna State, Nigeria. Specifically, the study objectives were to determine food security status, in terms of food availability, food accessibility and consumption pattern of the low-income households of selected Federal Tertiary Institutions in Kaduna state, Nigeria.

\section{Research Questions}

Research questions adopted for this study and for which answers were provided include the following:

1. What is the food security status in terms of food availability among low income households of selected Federal Tertiary Institutions in Kaduna State, Nigeria?

2. What is the food security status in terms of food accessibility and nutritional status of low-income households of selected Federal Tertiary Institutions in Kaduna state, Nigeria? 
Table 1. Distribution According To Households' Level of Food Adequacy

\begin{tabular}{|c|c|c|c|c|c|c|c|c|}
\hline \multirow[t]{2}{*}{ S/No } & \multirow[t]{2}{*}{ Food Groups } & \multicolumn{5}{|c|}{ Response Categories } & \multirow{2}{*}{$\begin{array}{l}\text { Means of } \\
\text { Adequacy }\end{array}$} & \multirow[t]{2}{*}{ Decision } \\
\hline & & $\begin{array}{l}\text { Very } \\
\text { Adequate } \\
\text { (5) }\end{array}$ & $\begin{array}{l}\text { Adequate } \\
\text { (4) }\end{array}$ & $\begin{array}{l}\text { Moderate } \\
\text { Adequacy } \\
\text { (3) }\end{array}$ & $\begin{array}{l}\text { Fairly } \\
\text { Adequacy } \\
\text { (2) }\end{array}$ & $\begin{array}{l}\text { Not } \\
\text { Adequate } \\
\text { (1) }\end{array}$ & & \\
\hline 1 & $\begin{array}{l}\text { Roots, Tubers \& } \\
\text { Cereals (yams, eba, } \\
\text { fufu, potatoes, tuwo, } \\
\text { bread, porridge etc) }\end{array}$ & 33 & 50 & 85 & 27 & 24 & 3.19 & Agreed \\
\hline 2. & $\begin{array}{l}\text { Legumes/Pulses/ } \\
\text { Vegetables }\end{array}$ & 152 & 38 & 11 & 16 & 2 & 4.47 & Agreed \\
\hline 3. & Fats \& Oils & 16 & 11 & 108 & 63 & 21 & 2.72 & $\begin{array}{l}\text { Not } \\
\text { Agreed }\end{array}$ \\
\hline 4. & $\begin{array}{l}\text { Fruits (oranges, } \\
\text { Banana pawpaw, } \\
\text { garden egg, Mango, } \\
\text { guava etc) }\end{array}$ & 69 & 24 & 101 & 18 & 7 & 3.59 & Agreed \\
\hline 5. & Meat /Fish/Eggs & 5 & 15 & 46 & 30 & 123 & 1.83 & $\begin{array}{l}\text { Not } \\
\text { Agreed }\end{array}$ \\
\hline 6. & Milk \& Milk Products & 12 & 52 & 47 & 40 & 68 & 2.54 & $\begin{array}{l}\text { Not } \\
\text { Agreed }\end{array}$ \\
\hline 7. & Beverages & 64 & 81 & 34 & 4 & 36 & 3.61 & Agreed \\
\hline
\end{tabular}

Decision rule $=3 \quad \mathrm{~N}=219$

3. What is the food security status in terms of consumption and nutritional status of low-income households of selected Federal Tertiary Institutions in Kaduna state, Nigeria?

\section{Null Hypothesis}

1. There is no significant relationship between food accessibility and nutritional status among low-income households of selected Federal Tertiary Institutions of Kaduna state, Nigeria.

2. There is no significant relationship between consumption pattern of food and nutritional status of the low- income households of selected Federal Tertiary Institutions in Kaduna state, Nigeria.

\section{METHODOLOGY}

Descriptive research approach was adopted in data collection because it involves collection and analysis of large data and information through questionnaire and interviews. Population for the study consists of lowincome families in seven (7) Federal Tertiary Institutions in Kaduna State. Total population of the household was 1552.

Multistage stratified random sampling for a population of 1552 was used to select sample size of 232 households. Sampling was done in stages. At first stage, Kaduna State was purposively selected out of the 36 states in Nigeria. Purposive sampling technique was also used at the second stage to select seven institutions; namely, Federal College of Education, Zaria, Samaru College of Agriculture, Ahmadu Bello University, Zaria, Federal Polytechnic, Kaduna, Nigeria College of Aviation Zaria, National Institute for Transport Technology (NITT), Zaria, and National Research Institute for Chemical Technology, Zaria. The institutions were chosen because they are federally sponsored; hence salary structure for staff member across them was uniform. In the third stage, the number of respondents' households from each institution was selected using proportionality sampling method of $15 \%$ to select, $50,25,40,46,29,14,28$ household heads respectively giving a total of 232 households for the study (Bello and Ajayi, 2000). These households were also selected based on their income level.

A structured questionnaire was used to obtain data. Questions were drawn based on the objectives, research questions and null hypotheses of the study. Statements having to do with food security (food availability accessibility and consumption pattern) of low-income households were contained in the questionnaire. The validity and contents of the instrument were done by three experts from Home Economics Section of 
Vocational and Technical Education Department, Ahmadu Bello University, Zaria, to upgrade quality of the questionnaire to aid valid data collection. Pilot study was carried out to test the instrument for the study. Twenty (20) low-income households from Federal College of Education, Kastina were used to pilot-test the instrument. Data collected from the pilot study, were statistically analyzed to get reliability co-efficient using Cronbach reliability co-efficient method. Statistical Programme for Social Science (SPSS) was used to calculate the Cronbach reliability co-efficient, alpha. A Cronbach's reliability co-efficient level of 0.98 for internal consistency was obtained

Descriptive statistics such as, frequencies, percentages and mean were used to describe the sociodemographic characteristics of respondents. Statistical Package for the Social Sciences (SPSS) $17^{\text {th }}$ version was used to test null hypotheses at $\mathrm{P}<0.005$ level of significance. Mean and standard deviation were used to compute food security status and nutritional status. A 5point, 7-point and 4-points Likert scale measurements were used to assess food security status at household level; where; 5- very adequate, 4- adequate, 3moderately adequate, 2- fairly adequate, and 0 - not adequate for food adequacy; 7- point scale where; 7daily, 6- twice daily, 5- thrice daily, 4- once daily, 3- twice weekly, 2- thrice weekly and 1- once a month for their food accessibility pattern. Food consumption pattern were; 4 for most often, 3 - often, 2- sometimes and 1 occasionally. The decision rules were 3 for food adequacy, 4 for food accessibility and 3 for consumption pattern. Pearson Product Moment of Correlation was used to test the hypothesis that involved two or more variables. The variables determined included food accessibility and nutritional status.

\section{RESULTS AND DISCUSSION}

\section{Research Question One: What is The Food Security Status in Terms of Food Availability of Low Income Households of Selected Federal Tertiary Institutions in Kaduna State?}

Table 1 presents level of food security in terms of food adequacy of low income households in selected Federal tertiary institutions in Kaduna state. Food items of legumes, pulses and vegetables were the most adequate food item to the low income households as this attracted highest mean response of 4.47. Table 1 show that this class of food was very adequate to 152 respondents and adequate to 38 others, moderately adequate to 11 respondents, fairly adequate to 16 others and not adequate to the rest 2 respondents. Also, fruits such as mangoes, guava were second most adequate food items as these attracted second highest mean response of 3.59. Table 1 also shows that fruits were very adequate to 69 respondents, adequate to 24 others, moderately adequate to 101 respondents, fairly adequate to 18 and not adequate to the rest 7 respondents. Roots, tubers and cereals; such as yams, tuwon (cereal flours), bread and others were the third adequate food items available to low-income families in the study area. These attracted third highest mean adequate response of 3.19. Results show that these were very adequate to 33 , adequate to 50 , moderately adequate to 85 , fairly adequate to 27 and not adequate to the rest 24 respondents (Table 1 ). Meat/fish and egg food items were least adequate to the low income households as they attracted the least mean adequacy level of 1.83 .

Table 1 details show that Meat/fish and egg food items were very adequate to 5 respondents, adequate to 15 others, moderately adequate to 46 , fairly adequate to 30 others and not adequate to majority respondents, numbering 123. Also, most adequate food items to the low income households in Federal tertiary institutions in Kaduna State were legumes/pulse/vegetables, followed by fruits (mangoes, guava etc), and roots/tubers/cereals (yams, bread, tuwon). Least food items to the low income households was meat/fish/eggs (beef, frozen fish etc) with 1.83 mean scores which was not adequate (Table 1). The results imply that food security in terms of food availability was adequate except in meat group.

\section{Research Question Two: What is the Food Security Status in Terms of Food Accessibility and Nutritional Status of Low-Income Households of Selected Federal Tertiary Institutions in Kaduna State, Nigeria?}

Table 2 revealed pattern of accessibility of food items by the low income household members of selected Federal tertiary institutions in Kaduna state. Cereals and cereals products were the most accessible, as these attracted the highest mean accessibility level of 5.97. Table 2 shows that 165 respondents daily accessed these food items, while 2 respondents accessed it twice daily. Thirteen (13) respondents' accessed cereals and cereals products thrice daily and 2 respondents accessed it once monthly. Other eleven respondent's accessed cereals twice daily and the rest 8 accessed it only once a month. The second most accessed food items to the respondents were vegetables and fruits with the second highest accessibility mean of 5.55 . The third was sugar and honey with a mean accessibility level of 5.23 . The least food in pattern of accessibility was meat/fish and egg products as this attracted least mean accessibility of 4.09. Table 2 shows that 58 respondents accessed meat/fish daily, while 3 respondents accessed it twice daily. Twelve respondents (12) accessed meat/fish thrice daily, while 51 respondents accessed it once weekly. Forty two (42) respondents accessed it twice monthly, while 31 respondents accessed it thrice monthly and the 
Table 2. Distribution of Households According to Opinion on Food Accessibility

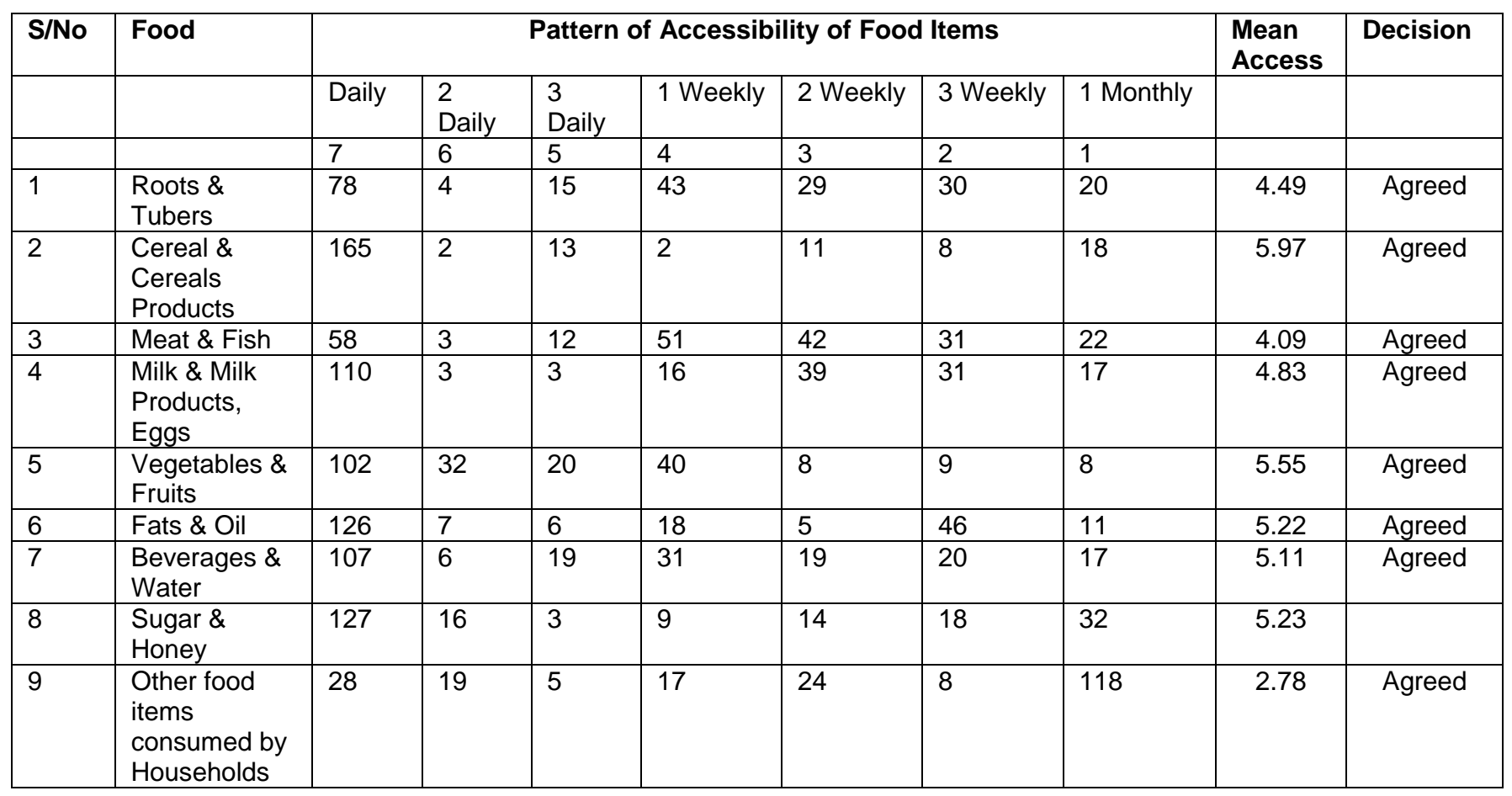

Decision rule $=4 ; \mathrm{N}=219$

rest 22 respondents accessed it once a month. This implies that most accessible food items was cereals and cereal products while the least accessible to the low income households was meat, fish and egg product. The implication of this is that food items that were easily accessible were those that were easy to purchase and store because of their low cost, while the relatively costlier ones were not accessible as income of the households might not support their purchase with its telling effects on accessibility.

\section{RESEARCH QUESTION 3: What is the Food Security Status in Terms of Consumption \\ Pattern and Nutritional Status among Low- Income Households of Selected Federal Tertiary Institutions in Kaduna State?}

The consumption pattern or regularity of food items by low income household respondents' is contained in Table 3. Grains (e.g. maize, millets etc) were most consumed food items by the low income households, as this attracted the highest mean consumption level of 3.33 (Table 3). Respondents consumption pattern show that 121 respondents consumed grains most often while 71 others consumed grains often. However, 6 respondents consumed grains sometimes, while the rest 21 respondents consumed grain food items occasionally. Legumes (e.g. beans, soya bean etc) were the second most consumed food items. Legume group of food items attracted the second highest mean consumption level of 2.76. Table 3 shows that 27 respondents consumed legumes most often, while 125 respondents consumed it often. Also, 55 respondents consumed legumes sometimes while the rest 12 respondents consumed it occasionally. Subsequently, the least consumed food items were meat (e.g. beef, goat meat etc) that attracted the least mean consumption level of 1.99. Table 3 also shows that only 7 respondents consumed meat most often while 37 others consumed it often. However, 123 respondents consumed meat sometimes while the rest 52 respondents consumed meat food items occasionally. This shows that the most consumed food items by the low income households was grains (e.g. maize, millets etc), while the least most consumed food items was meat or meat items. The implication of this is that with heavy consumption of grains nutritional status of the households could be skewed towards high intake of energy given foods.

In summary, food availability of low-income households was adequate on legumes/pulse/vegetables, beverages, fruits, roots and tubers and cereals. They were able to access cereal, vegetables/fruits, sugar and honey, fats and oil, milk and eggs, roots and tubers and finally meat and fish in that order. Therefore the lowincome households were food secured on cereals, legumes and vegetables, but were not able to sufficiently access meat and meat products. 
Table 3. Distribution of Households on Opinion on Food Consumption Pattern

\begin{tabular}{|c|c|c|c|c|c|c|c|}
\hline \multirow[t]{2}{*}{ S/No } & \multirow[t]{2}{*}{ Food Group } & \multicolumn{4}{|c|}{ Pattern of Food Consumption } & \multirow[t]{2}{*}{ Mean } & \multirow[t]{2}{*}{ Decision } \\
\hline & & $\begin{array}{l}\text { Most Often } \\
\text { (4) }\end{array}$ & $\begin{array}{l}\text { Often } \\
\text { (3) }\end{array}$ & $\begin{array}{c}\text { Sometimes } \\
(2)\end{array}$ & $\begin{array}{c}\text { Occasionally } \\
\text { (1) }\end{array}$ & & \\
\hline 1. & $\begin{array}{l}\text { Fruits (e.g., orange, } \\
\text { banana) }\end{array}$ & 3 & 44 & 133 & 39 & 2.05 & Not Agreed \\
\hline 2. & $\begin{array}{l}\text { Vegetables (e.g. okro, } \\
\text { spinach) }\end{array}$ & 4 & 82 & 111 & 22 & 2.31 & Not Agreed \\
\hline 3. & $\begin{array}{l}\text { Roots/tubers (e.g., } \\
\text { sweet potatoes, yam) }\end{array}$ & 7 & 76 & 103 & 33 & 2.26 & Not Agreed \\
\hline 4. & $\begin{array}{l}\text { Meat (e.g., beef, goat } \\
\text { meat) }\end{array}$ & 7 & 37 & 123 & 52 & 1.99 & Not Agreed \\
\hline 5. & $\begin{array}{l}\text { Fish (e.g. frozen fish, } \\
\text { dry fish) }\end{array}$ & 6 & 66 & 136 & 11 & 2.28 & Not Agreed \\
\hline 6. & $\begin{array}{l}\text { Grains (e.g. maize, } \\
\text { millet) }\end{array}$ & 121 & 71 & 6 & 21 & 3.33 & Agreed \\
\hline 7. & $\begin{array}{l}\text { Legumes (e.g. bean, } \\
\text { soya bean) }\end{array}$ & 27 & 125 & 55 & 12 & 2.76 & Not Agreed \\
\hline
\end{tabular}

Decision rule $=3 ; \quad \mathrm{N}=\mathbf{2 1 9}$

Table 4. Pearson Product Moment of Correlation Results on the Relationship Between Nutritional Status and Food Accessibility of Low- Income Households of Kaduna State

\begin{tabular}{lcccccr}
\hline Variable & N & Mean & $\begin{array}{l}\text { Standard } \\
\text { Deviation }\end{array}$ & Df & $\begin{array}{l}\text { Correlation } \\
\text { Index (r) }\end{array}$ & Sig (p) \\
\hline Food Accessibility & 219 & 31.4 & 6.98 & 217 & $0.67^{\star \star}$ & 0.000 \\
Nutritional Status & 219 & & 11.5 & 5.38 & & \\
\hline
\end{tabular}

Correlation is significant at the 0.005 level

\section{Testing Of Research Hypothesis}

The null hypothesis was tested at 0.005 alpha level of significant to find relationship between food accessibility and nutritional status among low-income households. The null hypothesis was rejected. Tables 4 and 5 contained results of null hypothesis. Pearson Product Moment of Correlation used to analyze the data.

\section{Null Hypothesis One:}

There is no Significant Relationship between Food Accessibility and Nutritional Status among LowIncome Households of Selected Federal Tertiary Institutions of Kaduna State, Nigeria

Outcome of the Pearson Product Moment Correlation (PPMC) statistics, in the Table 4 revealed that significant relationship exists between food accessibility and nutritional status of low income households of Federal Tertiary Institutions of Kaduna state. This could be because calculated $P$ value of 0.000 is less than 0.05 level of tolerance. The level of relationship between the two variables was high considering the correlation index level of 0.67 which is close to 1 . This outcome implies that food accessibility of the low income households has significant relationship with their nutritional status. Subsequently the null hypothesis was rejected.

\section{The Null Hypothesis 2:}

That There Is No Significant Relationship between Consumption Pattern of Food And Nutritional Status of Low-Income Households of Federal Tertiary Institutions of Kaduna State.

Table 5 outcome of the Pearson Product Moment Correlation (PPMC) statistics revealed significant 
Table 5. Pearson Product Moment of Correlation Results between Consumption Patterns of Food and Nutritional Status of Low-Income Households, Kaduna State

\begin{tabular}{lcccccc}
\hline Variables & N & Mean & $\begin{array}{l}\text { Standard } \\
\text { Deviation }\end{array}$ & Df & $\begin{array}{l}\text { Correlation } \\
\text { Index (r) }\end{array}$ & Sig (p) \\
\hline $\begin{array}{l}\text { Consumption Pattern } \\
\text { of Food }\end{array}$ & 219 & 22.31 & 4.01 & & & \\
Nutritional Status & 219 & 11.50 & 5.38 & 217 & $0.477^{\star \star}$ & 0.000 \\
\hline
\end{tabular}

Correlation is significant at the 0.005 level

relationship between regularity of food and Nutritional status of low income households in selected tertiary institutions, Kaduna state. This was because the calculated $P$ value of 0.000 was less than 0.05 level of tolerance. The level of relationship between the two variables was high, considering that the correlation index level was $0.477<0.05$. This outcome implies that the regularity of food consumed had significant $(P<0.05)$ influence on nutritional status of the low income household. The null hypothesis which states that there is no significant relationship between Regularity of food and Nutritional status of low income households in selected tertiary institutions, Kaduna state was rejected.

\section{DISCUSSION}

Outcome of the study revealed a significant relationship between food availability, food accessibility and nutritional status of the respondents. The result of findings could be as a result of available food items to the respondents, as it was discovered that majority of them supplemented what they used their salary to procure in terms of food items, from farming and home garden. This practice agrees with the position of World Food Summit (WFS), (1996) that one of the best ways to enhance nutritional status of family members; particularly in the third world countries, is to engage in production of both staple and none staple foods through home garden and farming. Accordingly, this is one way to increase the level of access family could have to food items.

Subsequently, cereals and cereal products were the most accessible food items to low-income households (Table 2). The results reveal that they accessed cereal food items daily, followed by vegetables and fruits, sugar and honey, fats and oils respectively. The least accessible among these food groups were milk and milk products and eggs, roots and tubers and meat and fish. These representations in terms of accessibility of cereals and cereal products agreed with Oyebanji (2005) that cereal was among the major crop production in Nigeria with 22,729 metric tons production each year. Similarly, Igba (2009) found that low-income families in Ebony state adopted home gardening; among others, as a strategy to alleviate poverty. Another reason for this outcome could be because most low- income earners settled for food items that were considered cheap and easy to buy. This availed them opportunity to provide adequate food items for themselves (Abdullahi, 1999).

Findings on relationship between consumption pattern of food and nutritional status on how regular foods were consumed, may have contributed significantly to nutritional status of low-income households (Table 3). The result therefore is an indication of significant relationship between consumption pattern and nutritional status. A possible reason for this outcome may be because of the spiral effect that regularity of food consumed may have in promoting nutritional status. For example August et al. (2002) suggested that timing is important for adequate feeding and that any form of achievable nutritional status is dependent on how regular and adequate that food was consumed. According to Baker (2003) for instance, any discussion on nutritional status must take cognizance of how regular food occur and in what proportion. The outcome in this regard may have arisen from the position earlier advocated by August et al. (2002). This outcome can also be viewed from the position canvassed by Brown (2005) that attention must always be paid to how often and regular human meals are consumed when nutritional status is concerned.

\section{CONCLUSION AND RECOMMENDATIONS}

Conclusions from findings of the study therefore, were that households in Federal tertiary institutions had adequate availability of legumes/vegetables, fruits, roots/tubers and cereals, accessed and consumed more cereals and cereals product foods. They however had low access and consumed little of animal protein. The low-income households were therefore food secured in legumes/vegetables, fruits and cereal.

i. The study recommend therefore that Health workers and Home Economics Extension Agents should create further education/awareness on the importance of animal protein, how to access and use them along with plant protein and vegetables through workshops, cluster group discussions, posters, radio and television jingles, to improve on consumption pattern and nutritional status of low-income households.

ii. Federal Ministry of Education should incorporate Food security education in school curricula at tertiary 


\section{institution levels in Home Management.}

\section{REFERENCES}

Abdullahi A(1999). Food Policy and Food Security In Nigeria. In Food Demand and Market Studies In The Drier Savanna Of Nigeria. Proceedings of A Methodology and Stakeholders Workshop. Kaduna State, Nigeria. Retrieved From http://www.foodafrica. nnri.org.2009.

Anderson SA(1990). Core Indicators of Nutritional State for Difficult-ToSample Population. Journal of Nutrition, 121, 600.

August DA, Teitelbaun D, Albina J, Bothe A, Guenter P, Heitkemper $\mathrm{M}(2002)$. Guidelines For The Use Of Parenteral And Enteral Nutrition In Adult And Enteral. Journal of Nutrition. 26 (1 .suppliment) 25.

Baker S(2003). Nutritional Status Of Low-Income Families. Journal Of Family And Consumer Science Trend Analysis. Retrieved from . http;//www.susan-baker@nesu.edu 2009

Bello R, Ajayi OOS(2000). Research Methods and Statistical Analysis. Ilorin Nigeria: Haylee Press and Publishing Company Limited.

Brown JE(2005). Nutrition Through The Life Cycle. Second Ed. U.S.A.: Publisher Thomson Wadsworth

Idachaba FS(2004). Food Security In Nigeria: Challenges Under Democracy Dispensation. In Uko- Aviornoh EE(2005). Family
Education, Vocationalism And Food Security Of The Nigerian Child. Journal Of Home Economics Research, 6 (2): 70-79.

Igba CE(2009). Family And Food Insecurity In Nigeria. Journal Of Home Economics Research Association. 5 (2): 119-125.

Obamiro EO, Doppler W, Kormawa PM(2003). Pillars of Food Security In Rural Areas Of Nigeria. Journal Of Food Africa, Internet Forum 1-6. Retrieved http://www.Obamiro@egiar.org 2008.

Ohwovoriole PI, Ochonogor EO(2009). Implementation Of Food And Nutrition Policy For Security In Nigeria. Perception Of Homemakers In Warn Metropolis. Journal Of Home Economics Research, 10 \& 11: $35-44$

Omonona BT, Adetokunbo AG(2007). An Analysis Of Food Security Situation Among Nigerian Urban Households: Evidence From Lagos State, Nigeria. Journal Of Central European Agriculture, 8(5): 397406.

Oyebanji OO(2005). Food Security Situation In Nigeria. CAFSTONDurbar Hotel Kano.

USAID(2009). Nigeria Food Security Update. Retrieved, http://www.fes.net./foodinsecurityscale 2010.

USAID, (2002). Population Reports In Series Of Maryland..

World Food Summit (WFS), (1996). World Food Summit Plan of Action. FAO, Rome. $13^{\text {th }}-17^{\text {th }}$ November, 1996. Retrieved. http://www.fao.org/docrep/003/w361e/w3613e00.htm 2008

Zeollick R(2008). Food Crises. How Prepared Is Nigeria? In Nigeria [Sunday THISDAY Newspaper]. April, 27, 2008. Pp 25. 